\title{
Logistics outsourcing and performance of manufacturing small and medium-sized enterprises in Nairobi
}

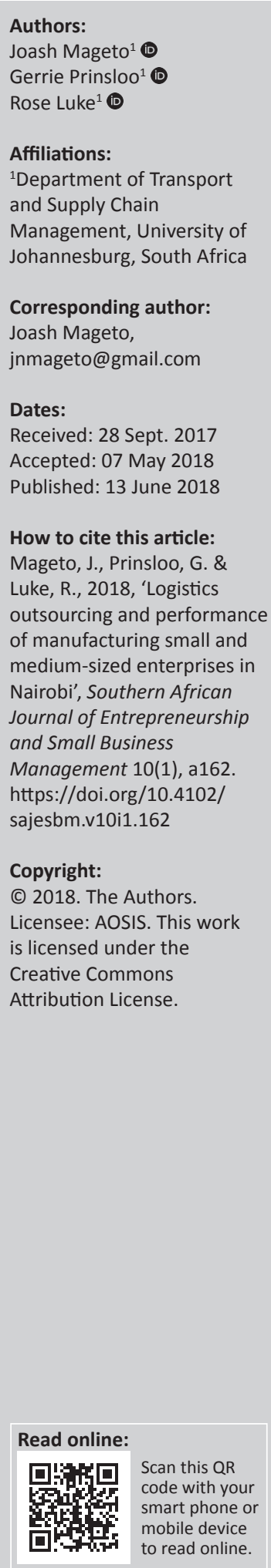

Background: Logistics outsourcing has been accepted as a strategy through which small and medium-sized enterprises (SMEs) can access the logistics capabilities they lack internally at a lower cost. However, the actual effect of logistics outsourcing on firm performance, especially among the SMEs in Nairobi, remains unknown.

Aim: The study aimed to investigate the relationship between logistics outsourcing and firm performance of manufacturing SMEs in Nairobi.

Setting: The study sampled manufacturing SMEs in Nairobi City County.

Method: In this study, a convergent parallel mixed methods design was applied. Survey data were collected from 163 manufacturing SMEs. The data were analysed using structural equation modelling to test the relationship between logistics outsourcing and firm performance. Additionally, in-depth interviews were conducted in five manufacturing SMEs. Thematic analysis was used to analyse interview data to provide more insight in the quantitative data.

Results: The anticipated direct link between logistics outsourcing and performance of manufacturing SMEs was not statistically significant. However, the study revealed a statistically significant indirect positive effect of logistics outsourcing on the performance of manufacturing SMEs through logistics outsourcing performance as a mediator variable. This article further highlights reasons and the process of logistics outsourcing and deduces a logistics outsourcing model for manufacturing SMEs to help improve their firm's performance.

Conclusion: The established relationship and deduced logistics outsourcing model is likely to guide SME managers as to how to manage logistics outsourcing to improve performance. The finding that logistics outsourcing has a positive indirect effect on the performance of manufacturing SMEs through logistics outsourcing performance makes a significant contribution to theory.

\section{Introduction}

Manufacturing small and medium-sized enterprises (SMEs) in Kenya have performed dismally over the years despite their significance to the economy (Government of Kenya 2012; Papadavid 2016). This can be attributed to the high levels of uncertainty in the business environment, high costs of production, as well as inefficient transport and logistics operations, which hamper the smooth movement of raw materials to site and finished goods to the market (Chege, Ngui \& Kimuyu 2016; Kimuyu 2010). In addition, SMEs operate in an environment characterised by rapid changes in technology, intense competition from Chinese products, dynamic customer requirements and the growing need for efficiency, high-quality products and increased productivity (Bowen, Morara \& Mureithi 2009; Chew \& Chew 2008; Were 2016). The poor performance of SMEs in Kenya has limited the benefits the sector should be providing to the government and other stakeholders, such as job creation, poverty reduction and industrialisation (Buculescu 2013). Were (2016) argues that the continued poor performance threatens the survival of the SME sector in Kenya. Thus, there is enormous pressure on the management of SMEs to take strategic decisions to improve performance (Murphy et al. 2012). Owing to limited resources in SMEs, they are compelled to allocate their meagre and hard-won resources to those areas of production that can generate the highest returns for shareholders (Murphy et al. 2012). This means that manufacturing SMEs should focus their limited resources on core business areas and outsource the non-core but essential functions to reduce costs and increase customer satisfaction (Solakivi et al. 2011; Sople 2012). One of the essential non-core areas that present an opportunity for improved performance of manufacturing SMEs if outsourced is logistics (Waugh \& Luke 2011). Logistics outsourcing 
allows enterprises to access capabilities they lack in-house, as per the resource-based view (RBV) theory, and at a lower cost than owning, as outlined by the proponents of transaction cost economics (TCE) theory (Halldorsson et al. 2007).

There are several studies that have investigated logistics outsourcing and firm performance (Cho, Ozment \& Sink 2008; Kotabe \& Mol 2009; Solakivi et al. 2011). However, the actual effect of logistics outsourcing on firm performance remains unknown as there is no consensus among the researchers as to whether the practice leads to improved firm performance (Kotabe \& Mol 2009; Lahiri 2015). Some studies have claimed that logistics outsourcing has no effect on firm performance (Hsiao et al. 2010; Töyli et al. 2008). Cho et al. (2008) argued that logistics outsourcing can affect firm performance negatively, whereas Parashkevova (2007) claimed that it results in improved firm performance. Based on the divergent views among researchers, this study highlights that little is known about the relationship between logistics outsourcing and the performance of manufacturing SMEs, specifically in Nairobi. This study investigated the relationship using a theoretical framework that draws from the RBV and the TCE theory. Therefore, the study sought to answer the following research questions:

- Why do manufacturing SMEs practice logistics outsourcing?

- How do manufacturing SMEs outsource logistics?

- What is the relationship between logistics outsourcing and performance of manufacturing SMEs?

In this study, the relationship between logistics outsourcing and performance of SMEs has been established empirically. In addition, it advances logistics literature by proposing a logistics outsourcing model that SMEs can be applied to improve their firm's performance. The remainder of this article addresses the importance of SMEs in Kenya, logistics outsourcing and firm performance, methodology, findings, discussion and, finally, the conclusion.

\section{Literature review}

In this section, literature related to the importance of SMEs in Kenya, logistics outsourcing and firm performance is reviewed. This helped to develop a conceptual framework at the end of this section.

\section{Importance of small and medium-sized enterprises in Kenya}

The significance of SMEs to the economic growth and development of both developed and developing countries is recognised across the world (Nasr \& Rostom 2013). SMEs require little capital to set up and have the potential to create jobs for the burgeoning number of unemployed youths in most developing countries (Gill \& Biger 2012; Sonobe, Akoten \& Otsuka 2011). Manufacturing SMEs boost economic activities in the areas in which they operate, because they produce goods that meet the immediate needs of locals, thus serving a market that the large enterprises have ignored (Chege et al. 2016; Sonobe et al. 2011). In Kenya, manufacturing
SMEs account for about $80 \%$ of the number of firms in the manufacturing sector and employ over $80 \%$ of the workforce in this sector (Kenya National Bureau of Statistics 2016). To further emphasise the importance of SMEs to development, the Kenyan government recognised the sector in its 'Kenya vision 2030' strategic plan for its role in the country's industrialisation agenda (Government of Kenya 2007).

There are case studies of countries across the globe such as China (Chen 2006), Malaysia (Karikomi 1998) and India (Das 2008) that have industrialised by focusing on small and medium-sized manufacturers. This implies that countries in sub-Saharan Africa such as Kenya can also facilitate industrialisation by focusing on the development of manufacturing SMEs. However, as highlighted earlier, SMEs face resource challenges, making it difficult to own capabilities that can enable efficient and effective operations (Bowen et al. 2009). Some of the capabilities required by SMEs, especially in logistics, can easily be accessed through outsourcing (Murphy et al. 2012). It is expected that SMEs are more likely to focus on the quality of goods and distribute widely at lower costs, resulting in improved firm performance, once they contract expert logistics service providers (LSPs) (Soinio, Tanskanen \& Finne 2012).

\section{Logistics outsourcing and firm performance}

Logistics outsourcing refers to the transfer of all or part of the logistics functions to be performed on behalf of the firm by third-party logistics service providers (Lieb \& Randall 1996; König \& Spinler 2016; Van Laarhoven, Berglund \& Peters 2000). Pratap (2014) argued that logistics outsourcing can best be explained by the RBV and TCE theories. The RBV theory holds that an enterprise can acquire resources and capabilities through outsourcing to meet its customers' needs (Wong \& Karia 2010). Similarly, the TCE theory highlights that logistics outsourcing provides an avenue for conducting business at lower transaction costs when compared to in-house operations, thus improving firm performance (Bolumole, Frankel \& Naslund 2007; Pratap 2014). The RBV and TCE theories have been applied extensively in logistics outsourcing research (Liu et al. 2015; Pratap 2014), depicting their relevance to guiding development of predictive models in logistics management. Past research has identified the increased importance of logistics across the globe in determining overall firm performance, as supply chains become complex (König \& Spinler 2016), thus reinforcing the importance of this study.

The growing significance of logistics among firms can further be revealed by the increased spending and its central role in improving customer service (Langley \& Capgemini 2016). As logistics performance becomes more significant, firms are expected to focus on their core business areas, leaving logistics to be outsourced to expert LSPs (König \& Spinler 2016; Rahman \& Wu 2011). Using LSPs implies that the firms (in this case manufacturing SMEs) would access the logistics capabilities they lack in-house, as they focus on their core 
manufacturing activities to improve performance (König \& Spinler 2016; Langley \& Capgemini 2016; Murphy et al. 2012). Thus, it is hypothesised that:

- Logistics outsourcing has a positive effect on firm performance

Logistics outsourcing is also adopted to reduce logistics costs and as a long-term strategy to increase customer satisfaction and improve overall enterprise performance (Fawcett, Magnan \& McCarter 2008; Lee, Lin \& Cheng 2013). Logistics activities that are commonly outsourced can be classified into operational (transportation, fleet management, clearing and forwarding), information processing (logistics information system, procurement and order management, product track and trace), and strategic and value-adding services (inventory, warehousing and packaging management) (Langley \& Capgemini 2016; Liu et al. 2015; Solakivi et al. 2011).

Firm performance refers to how well a firm achieves its overall goals, both financial and non-financial (Kasie \& Belay 2013; Quang et al. 2016). Financial measures such as return on assets (ROA) and profitability are objective as they make use of actual figures, whereas the non-financial measures, such as customer satisfaction, use perception and are generally subjective (Tseng \& Liao 2015; Yang, Marlow \& Lu 2009). Measuring firm performance is not an easy task as one should select the most appropriate measures for the industry, period (long-term and short-term) and firm size to achieve the desired results (Kasie \& Belay 2013; Quang et al. 2016). As such, because SMEs lack clear management structures, the specific performance metrics selected, should be growth based and should focus on financial liquidity and customer satisfaction (Marchand \& Raymond 2008; Raymond et al. 2013). Therefore, this study measured performance of manufacturing SMEs through growth in sales, profits, ROA, return on capital employed (ROCE), earnings before interest and tax (EBIT), number of employees and customer satisfaction (Solakivi et al. 2011; Tseng \& Liao 2015).

High-performing SMEs are likely to deliver goods to meet local demand, create employment and improve living standards of communities where they operate (Chege et al. 2016; Nasr \& Rostom 2013). Thus, improving the performance of manufacturing SMEs will go a long way to improving not only livelihoods but also economic growth. This study highlights that logistics presents the potential to improve the performance of SMEs if managed diligently (Waugh \& Luke 2011). Logistics outsourcing has emerged as one such strategy that can be used to realise efficient and effective logistics operations, as the expertise of third-party logistics (3PLs) can be utilised (Waugh \& Luke 2011). Although the common view is that logistics outsourcing leads to improved enterprise performance (Fawcett et al. 2008; Langley \& Capgemini 2017), the actual relationship between logistics outsourcing and firm performance has not been established precisely in past research. Some past research has observed that logistics outsourcing improved firm performance (Lee et al. 2013; Parashkevova 2007), whereas Cho et al.'s (2008) study reported a negative relationship between logistics outsourcing and firm performance and Solakivi et al.'s (2011) study found no relationship with firm performance among Finnish SMEs. Therefore, this study sought to empirically investigate the relationship between logistics outsourcing and performance of small and medium-sized manufacturing enterprises in Nairobi.

Logistics outsourcing allows the SMEs to access capabilities of expert LSPs to achieve high logistics performance in terms of reduced cycle times, reduction of wasteful operations, increased flexibility, delivery timeliness and smooth operations in upstream and downstream activities (Green, Whitten \& Inman 2008; Zailani et al. 2017). Green et al. (2008) argued that increased logistics performance positively influences firm performance. As such, it is hypothesised as follows:

- Logistics outsourcing has a positive effect on logistics performance.

- Logistics performance has a positive effect on firm performance.

Logistics outsourcing performance refers to the extent to which LSPs meet a firm's expectations (Wagner \& Franklin 2008). Logistics outsourcing processes that take into consideration communication, trust levels, cooperation and innovation are likely to result in high logistics outsourcing performance (Deepen et al. 2008; Križman \& Ogorelc 2010; Oshri, Kotlersky \& Gerbasi 2015). In addition, Leuschner et al. (2014) highlight that logistics outsourcing performance positively affects logistics performance and consequently firm performance. Therefore, it is hypothesised as follows:

- Logistics outsourcing has a positive effect on logistics outsourcing performance.

- Logistics outsourcing performance has a positive effect on logistics performance.

- Logistics outsourcing performance has a positive effect on firm performance.

The relationship is investigated directly and indirectly through logistics outsourcing performance and logistics performance as mediating variables. The measures of logistics outsourcing performance in this study focus on the quality of communication and cooperation between SMEs and 3PLs (Deepen et al. 2008), trust levels (Huo, Ye \& Zhao 2015) and innovative capabilities of the 3PLs (Oshri et al. 2015). Logistics performance is measured by operational efficiency and customer service indicators (Zailani et al. 2017). Finally, it is hypothesised as follows:

- Logistics outsourcing performance mediates the relationship between logistics outsourcing and firm performance.

- Logistics performance mediates the relationship between logistics outsourcing and firm performance.

These relationships are conceptualised, as illustrated in Figure 1.

The model (Figure 1) was used to test six hypotheses using structural equation modelling. Additionally, mediation 


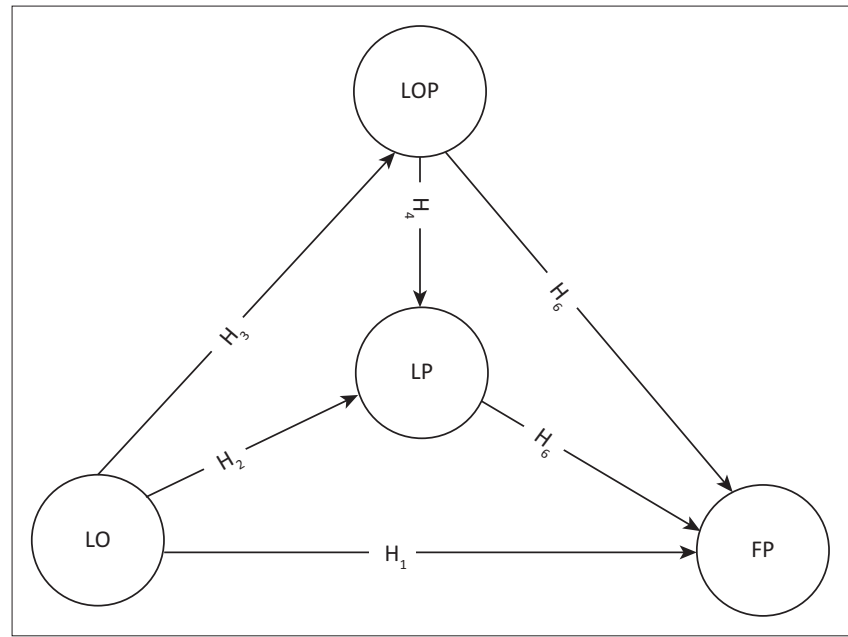

LO, logistics outsourcing; LOP, logistics outsourcing performance; LP, logistics performance $F P$, firm performance; $H$, Hypotheses.

FIGURE 1: Conceptual framework for logistics outsourcing.

hypotheses were tested to measure the indirect effect of logistics outsourcing (LO) on firm performance (FP) through logistics outsourcing performance (LOP) and logistics performance (LP). Thus, the study tested the following hypotheses:

- $\mathbf{H}_{\mathbf{1}}$ : Logistics outsourcing has a positive effect on firm performance.

- $\mathbf{H}_{2}$ : Logistics outsourcing has a positive effect on logistics performance.

- $\mathbf{H}_{3}$ : Logistics outsourcing has a positive effect on logistics outsourcing performance.

- $\mathbf{H}_{4}$ : Logistics outsourcing performance has a positive effect on logistics performance.

- $\mathbf{H}_{5}$ : Logistics outsourcing performance has a positive effect on firm performance.

- $\mathbf{H}_{6}$ : Logistics performance has a positive effect on firm performance.

- $\mathbf{H}_{7}$ : Logistics outsourcing performance mediates the relationship between logistics outsourcing and firm performance.

- $\mathbf{H}_{8}$ : Logistics performance mediates the relationship between logistics outsourcing and firm performance.

\section{Research methods and design}

This section presents first the research design followed in this study. Thereafter, the qualitative and quantitative approaches are described as used in this study.

\section{Research design}

The uniqueness of the SME context from industry to industry and even country to country calls for combined methods to better address the research questions, as claimed by Saunders, Lewis and Thornhill (2016). This study therefore adopted a pragmatist's philosophical orientation, which allows for a mixture of qualitative and quantitative research approaches in a single study (Takkashori \& Teddlie 2010), that is, a mixed methods research design (MMD). MMD refers to the use of both qualitative and quantitative approaches to address a research problem (Creswell \& Clark 2007; Jogulu \& Pansiri 2011). The use of this design helped to answer the 'why' and 'how' research questions that required qualitative data and the 'what' question which required quantitative data. The quantitative approach helped to test the application of RBV theory to logistics outsourcing. The results from the qualitative approach enriched the quantitative findings and helped advance logistics management literature regarding performance of SMEs. The results from the two approaches were interpreted together to provide a comprehensive response to the research questions as opposed to using either of the approaches (Saunders et al. 2016). Convergent parallel design variant of MMD was used in this study, whereby quantitative and qualitative data were collected and analysed concurrently (Jogulu \& Pansiri 2011). The qualitative approach was used to collect data that helped interpret the relationships tested between logistics outsourcing and firm performance. These two approaches were thus able to complement each other. Upon analysis of the data, the findings were interpreted together, whereby results from the qualitative approach helped explain the relationship with logistics outsourcing, hence addressing the research problem adequately (Creswell \& Clark 2011). Specifically, qualitative data helped explain why SMEs outsource logistics services as well as the process they follow to outsource. This provided insights of the kind of statistical relationships that could be expected between logistics outsourcing and performance of the SMEs. The combination of qualitative and quantitative approaches overcame the shortcomings such as the bias of relying on a single approach, by providing triangulated data to study the research problem (Creswell \& Clark 2011). The sampling techniques, instrument development and data collection are discussed in the following sections starting with the qualitative approach.

\section{Qualitative approach}

Purposive sampling was used to select five manufacturing SMEs, which participated in the interviews. It was used to select the manufacturing SMEs to provide rich data (Creswell 2014) regarding logistics outsourcing and firm performance. The enterprises selected represented the five main manufacturing categories in Kenya, as identified by Chege et al. (2016). Collecting data from multiple SMEs helped cross-checking to ensure that credible data were obtained.

Qualitative data were collected through face-to-face interviews using a semi-structured interview guide at the manufacturing SMEs' site. Conducting the interviews on site helped observe that actual manufacturing was taking place. The interview guide was piloted with two logistics managers. The piloting helped to adjust some questions which were not clear and drop others that were repetitive. In-depth interviews were conducted with directors or owners or managers in charge of logistics in their respective manufacturing SMEs. One interview was conducted in each of the SMEs. The selected respondents were those with all the relevant information 
regarding the enterprises' logistics management practices. The five interviews were sufficient as there was no additional information obtained after the fifth interview. The five interviews were sufficient, considering the claim by Creswell and Clark (2007) and Jogulu and Pansiri (2011) that four to five case studies are appropriate to meet the requirements of a mixed methods design. Three interviews were recorded using an audio recorder, whereas two were captured in interview notes.

The qualitative data were analysed through thematic analysis to answer the why and how research questions (1 and 2, respectively). Thematic analysis involved searching for themes across the interview data, as described by Saunders et al. (2016). The qualitative data collected through in-depth interviews were transcribed and coded. Themes related to the research questions 1 and 2 were identified. The research process followed in the qualitative approach is outlined in Figure 2.

\section{Quantitative approach}

The units of analysis comprised manufacturing SMEs in Nairobi. The study population encompassed 406 manufacturing SMEs in Nairobi as of 01 March 2015 as per the Nairobi City County (NCC) Licensing Department. Only SMEs engaged in manufacturing within NCC were counted as units of analysis. SMEs within the manufacturing sector that were engaged in trading or were service orientated were excluded. As such, actual manufacturing was observed during data collection, otherwise the enterprise was excluded. All other manufacturing firms were included in the study, regardless of the use of 3PL services. This inclusivity allowed for the determination of the extent of logistics outsourcing within the SMEs.

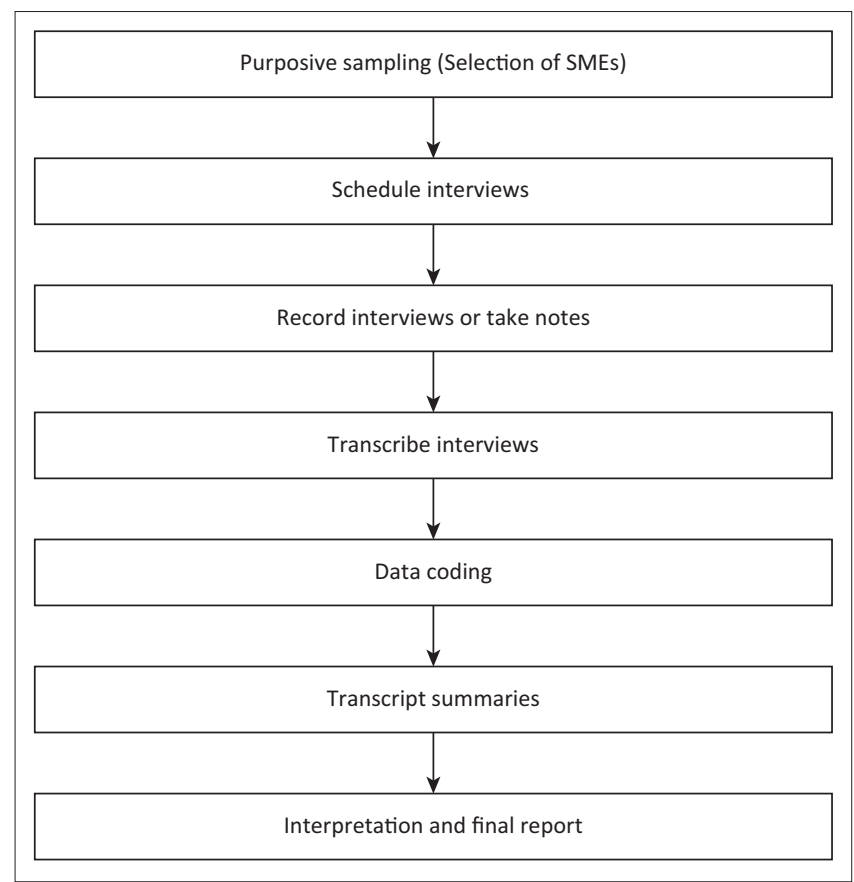

FIGURE 2: Qualitative research approach process.
Quantitative data were collected using a seven-point Likert-type survey questionnaire with end-points defined to help respondents understand the scale. Although there is no preferred number of points that specific rating scales should have, Krosnick and Presser (2010) argue that a lengthy scale (e.g. 7-point scale) may increase data validity compared to a 5-point scale. In addition to this, the 7-point scale was considered appropriate for this study because of the successful application of the same scale length in past studies (Cho et al. 2008; Liu et al. 2015). The questionnaire collected data on enterprise demographics, logistics outsourcing, logistics outsourcing performance, logistics performance and firm performance. Logistics outsourcing was measured by six items, which were self-developed in line with Langley and Capgemini (2016) and Solakivi et al. (2011). Logistics outsourcing performance was measured by 15 items comprising communication, trust, cooperation and innovation indicators (Deepen et al. 2008; Križman \& Ogorelc 2010). Logistics performance was measured using five items adapted from Green et al. (2008). Similarly, firm performance was also measured by five items (Solakivi et al. 2011; Yang et al. 2009). The questionnaire was piloted among ten manufacturing SME managers involved in the day-to-day management of logistics in their enterprises. The piloting exercise led to rewording of some items to make them clear before the data collection.

The drop and pick later method was used to collect quantitative data from SME managers in charge of logistics operations. In some cases, the questionnaires were filled on the spot. In instances of collect later, three attempts (spaced one week apart) were made to collect the filled questionnaire. Any questionnaires that were not collected within the three attempts were counted as not returned. The method was appropriate as only the physical and postal addresses of the manufacturing SMEs were available at the NCC Licensing Department. Although some respondents promised to email or send the filled questionnaires through postal services, none of these were received through post or email.

The quantitative data were analysed using partial least squares structural equation modelling (PLS-SEM) to investigate the relationship between logistics outsourcing and performance of manufacturing SMEs. The study selected the PLS-SEM technique because of its predictive performance (Davcik 2014; Richter et al. 2016). Prior to SEM, the data were tested on suitability for exploratory factor analysis (EFA) using the Kaiser-Meyer-Olkin and Bartlett tests (Pallant 2010). EFA was performed, and it identified the latent constructs scales. The scales' reliability was tested and found satisfactory in preparation for confirmatory factor analysis using Smartpls 3 (Ringle, Wende \& Becker 2015).

\section{Ethical consideration}

Ethical clearance was obtained from the relevant authorities within the university as an assurance that carrying out the study did not endanger any person or community. Acceptable research ethics were observed during planning, fieldwork, 
data analysis and reporting. For instance, participation in the study was voluntary and respondents could withdraw at any stage. Respondents were assured of anonymity of their responses. Participants were also informed that the study was only for academic purposes. This means that the participants did not suffer any loss during or after the study. Those who wanted to have access to the final report were given contacts through which they could make their requests.

\section{Results}

The enterprises that participated in the qualitative approach included the following: (1) a metal fabricator that manufactures meter boxes and cable trucking accessories, with 25 employees; (2) an industrial chemical manufacturer with 93 employees; (3) a paper products manufacturer, employing 15 people; (4) a food (spices and snacks) manufacturer with 90 employees and (5) a clothes manufacturer with 17 full-time employees.

The enterprises outsourced logistics services to reduce costs associated with investing in logistics fixed assets, inventory and operations. The industrial chemical manufacturer highlighted that in addition to cost reduction, the enterprise wanted to minimise the risks associated with managing logistics in-house. The respondent from the enterprise observed that:

\begin{abstract}
'... in terms of transportation cost we were okay with our inhouse team, but the invisible costs of transportation were very high. For instance, we could load a full truck and it is hijacked on the way. We lose the truck and all the goods. With outsourcing security of our goods in transit is not our concern as our LSPs take care of that ... we outsource to reduce transport risk.' (Participant from Enterprise 2, Male, Head of Production and Dispatch)
\end{abstract}

Logistics outsourcing helped the enterprises to focus on manufacturing. Running logistics in-house means more employees and management time. The respondent from the metal fabricator noted:

\footnotetext{
'... imagine what will happen when a vehicle in transit breaks down at night. The stress we will undergo is a lot. Our transport service providers are helping us a lot.' (Participant from Enterprise 1, Male, Supervisor)
}

Some of the enterprises, for example, the clothes manufacturer, highlighted that they lacked resources to invest in in-house logistics, and hence, they relied on outsourcing. In addition to the reasons offered above, the enterprises also observed that they adopted the use of 3PLs so as to achieve flexibility, timely deliveries, eliminate idle capacity of fixed assets, achieve high customer satisfaction and increased profits.

Based on the interview data, the enterprises highlighted that logistics outsourcing process must be managed diligently to accrue the expected benefits especially in the improvement of enterprise performance as also argued in the Waugh and Luke (2011) study. Three out of five of the manufacturing SMEs highlighted that they used ad hoc models to outsource logistics, whereas the other two had procurement guidelines that directed the outsourcing process. The ad hoc logistics outsourcing process was used to select the activities to be outsourced and the LSP. That is, they did not have a clear procedure to identify which logistics activity should be outsourced and to what degree, how to select a 3PL service provider and a contract outlining performance expectations from the prospective LSP. The enterprises that had guidelines, namely the metal fabricator, noted that '... our firm follows the procurement process as documented in our standard operating procedures and it helps us choose the right LSP $^{\prime}$ (participant from enterprise 1, male, supervisor). This could imply that price (lowest bidder) was the key determinant in selecting a 3PL. Although some manufacturing SMEs had clear guidelines of managing the purchase process, they lacked a specific process for logistics outsourcing that will lead to improved firm performance. For instance, once a decision was made on which logistics activity to outsource, the SMEs selected the 3PL service provider on the basis of price only. However, it may be difficult to achieve timely deliveries and high customer satisfaction through such a process. Hence, the need to develop a model that will help SMEs select the right LSP to improve performance. Analysis of data related to the survey is reported in the following paragraphs.

A total of 163 complete questionnaires were returned resulting in a $40.2 \%$ response rate. Non-response bias was ruled out based on the Armstrong and Overton (1977) study guidelines, entailing categorising the questionnaires into early responses and late responses. The late responses included questionnaires received after second and third collection attempts. This resulted in 141 and 21 questionnaires in the early and late responses categories. Non-response bias was tested by comparing mean for early and late responders, using logistics outsourcing and firm performance as the 'test variables' (Table 1). For both test variables, non-response bias was ruled out as there was no statistically significant $(p>0.05)$ difference between the responses of early and late responders (Table 1). The enterprises that participated in the survey were grouped into various manufacturing categories with 39.3\% being from chemical and plastics category, metal processors accounted for $25.2 \%$, wood and paper accounted for $16.6 \%$, $12.3 \%$ represented food and animal feeds category, while clothing and textiles accounted for only $6.7 \%$. About $80 \%$ of the enterprises had between 11 and 50 employees, whereas the rest had 51 to 100 employees. The demographics also revealed that the majority $(52.1 \%)$ of the enterprises had $<5$ years' experience with logistics outsourcing, $24.5 \%$ had 6-10 years' experience and the rest had over 10 years' experience.

The quantitative data were certified suitable for EFA after revealing a Kaiser-Meyer-Olkin value of 0.894 and a statistically significant $(p<0.05)$ Bartlett's test (Pallant 2010). All the manifest indicators were modelled as reflective in this study. The indicators were subjected to a first round of EFA using the principal component analysis method and Varimax rotation, but resulted in a suboptimal solution as some factors 
TABLE 1: Independent samples test for early and late respondents.

\begin{tabular}{|c|c|c|c|c|c|c|c|c|c|}
\hline \multirow[t]{3}{*}{ Item } & \multicolumn{2}{|c|}{$\begin{array}{l}\text { Levene's test for } \\
\text { equality of variances }\end{array}$} & \multicolumn{7}{|c|}{$t$-test for equality of means } \\
\hline & \multirow[t]{2}{*}{$\boldsymbol{F}$} & \multirow[t]{2}{*}{ Sig. } & \multirow[t]{2}{*}{$t$} & \multirow[t]{2}{*}{$d f$} & \multirow[t]{2}{*}{ Sig. (2-tailed) } & \multirow{2}{*}{$\begin{array}{c}\text { Mean } \\
\text { difference }\end{array}$} & \multirow{2}{*}{$\begin{array}{l}\text { Std. error } \\
\text { difference }\end{array}$} & \multicolumn{2}{|c|}{$95 \%$ confidence interval of the difference } \\
\hline & & & & & & & & Lower & Upper \\
\hline LO & 1.362 & 0.245 & 0.003 & 161 & 0.998 & 0.00091 & 0.31299 & -0.61719 & 0.61901 \\
\hline FP & 2.081 & 0.151 & -0.487 & 161 & 0.627 & -0.11241 & 0.23070 & -0.56799 & 0.34317 \\
\hline
\end{tabular}

LO, logistics outsourcing; FP, firm performance; Sig., significance; Std., standard.

Note: All probabilities at $95 \%(p<0.05)$.

had low loadings. The factors with low loading were eliminated, and a second round of EFA was performed, resulting to four components accounting for $61.2 \%$ of the total variance explained. Each of the components had more than three indicators loading on it, revealing an optimal solution (Pallant 2010). The structure of the components revealed that the latent constructs were LOP, LP, LO and FP, as outlined in Table 2. Confirmatory factor analysis was conducted using Smartpls 3.0 (Ringle et al. 2015) for the SEM technique, in order to investigate the relationship between LO and FP directly and indirectly through LOP and LP as mediator constructs. The final model indicator loading after confirmatory factor analysis is illustrated in Table 2 . All the indicators' loading ranged from 0.653 to 0.876 revealing substantial loading to the respective constructs.

The SEM technique requires that the final model's goodness of fit should be assessed. According to Hair et al. (2014), the final SEM model should be evaluated for goodness of fit by examining the outer and inner models. The outer model reveals how the manifest variables relate to the latent variables (Hair et al. 2014). The outer model is evaluated by checking internal consistency, convergent and discriminant validity (Davcik 2014; Hair et al. 2014). Cronbach's alpha values for each of the scales were $0.81,0.95,0.88$ and 0.87 for all the LO, LOP, LP and FP scales, respectively, revealing high internal consistency (Hair et al. 2014; Pallant 2010). The composite reliability values (FP: 0.90, LO: 0.81, LOP: 0.95 and LP: 0.91) also revealed high internal consistency for the model. The average variance extracted (AVE) values (LO: 0.56, FP: 0.65, LOP: 0.61 and LP: 0.67$)$ were all above 0.5 revealing that the model explained over 50\% of the variance (Davcik 2014; Hair et al. 2014).

Discriminant validity problems were ruled out from the model as per Fornell-Larcker criterion and absence of the cross-loading problem among the manifest variables (Hair et al. 2014). Table 3 illustrates a summary of the outer model's goodness of fit evaluation.

The inner model's goodness of fit was evaluated by examining collinearity, coefficient of determination $\left(R^{2}\right)$, predictive relevance $\left(Q^{2}\right)$, effect size $\left(f^{2}\right)$ and significance of the path coefficients (Hair et al. 2014). The variance inflation factor (VIF) values for the model were between 1.0 and 4.78 , which was below the critical value of 5.0 revealing no collinearity problem (Hair et al. 2014). The $R^{2}$ values for the study model revealed moderate predictive accuracy for FP (0.285) and LP (0.207), while it was weak for LOP (0.144) (Chin 1998).
TABLE 2: Indicator outer loadings extracted from final structural equation modelling model.

\begin{tabular}{|c|c|c|}
\hline Construct & Indicator description & $\begin{array}{l}\text { Indicator } \\
\text { loading }\end{array}$ \\
\hline \multirow[t]{3}{*}{ LO } & Clearing and forwarding. & 0.705 \\
\hline & Product tracking and tracing. & 0.876 \\
\hline & Packaging. & 0.653 \\
\hline \multirow[t]{15}{*}{ LOP } & $\begin{array}{l}\text { There is mutual respect between our enterprise and } \\
\text { outsourced LSPs. }\end{array}$ & 0.730 \\
\hline & LSPs can be depended on to deliver services. & 0.739 \\
\hline & $\begin{array}{l}\text { LSPs take the objectives of our enterprise into } \\
\text { consideration when making decisions that will affect } \\
\text { our business. }\end{array}$ & 0.711 \\
\hline & LSPs are dedicated to improving quality. & 0.836 \\
\hline & $\begin{array}{l}\text { LSPs are dedicated to eliminating waste or non-value- } \\
\text { adding processes. }\end{array}$ & 0.754 \\
\hline & $\begin{array}{l}\text { Our organisation can count on the LSPs to be honest } \\
\text { during contracting (e.g. not withhold relevant } \\
\text { information). }\end{array}$ & 0.798 \\
\hline & $\begin{array}{l}\text { There is mutual exchange of information between our } \\
\text { company and LSPs. }\end{array}$ & 0.820 \\
\hline & $\begin{array}{l}\text { Information is shared between parties in a timely manner } \\
\text { (e.g. no delays). }\end{array}$ & 0.843 \\
\hline & $\begin{array}{l}\text { The information received by either side is complete } \\
\text { (e.g. no loose ends). }\end{array}$ & 0.857 \\
\hline & $\begin{array}{l}\text { The information shared between our enterprise and LSPs } \\
\text { is accurate (e.g. straightforward). }\end{array}$ & 0.800 \\
\hline & $\begin{array}{l}\text { The information shared between our enterprise and LSPs } \\
\text { is clear. }\end{array}$ & 0.843 \\
\hline & $\begin{array}{l}\text { LSPs always provide practical solutions to problems } \\
\text { within their area of engagement. }\end{array}$ & 0.766 \\
\hline & $\begin{array}{l}\text { LSPs usually modify the performance of logistics activities } \\
\text { and processes to adapt to a changing environment. }\end{array}$ & 0.731 \\
\hline & $\begin{array}{l}\text { LSPs advise management on the improvement of } \\
\text { activities in areas outside their direct responsibility. }\end{array}$ & 0.684 \\
\hline & $\begin{array}{l}\text { LSPs sustain vibrant networks to deliver a valued service } \\
\text { to our enterprise. }\end{array}$ & 0.740 \\
\hline \multirow[t]{5}{*}{ LP } & Maintaining accurate records is ... & 0.809 \\
\hline & Consistently delivering quality goods and/or services is ... & 0.780 \\
\hline & Handling special orders is ... & 0.838 \\
\hline & $\begin{array}{l}\text { Modifying order size, volume or composition during a } \\
\text { logistics operation is ... }\end{array}$ & 0.825 \\
\hline & $\begin{array}{l}\text { Maintaining a seamless upstream and downstream flow } \\
\text { of goods is ... }\end{array}$ & 0.842 \\
\hline \multirow[t]{5}{*}{ FP } & Growth in profitability has been ... & 0.811 \\
\hline & Growth in return on total assets (ROA) has been ... & 0.832 \\
\hline & Growth in return on capital employed (ROCE) has been ... & 0.845 \\
\hline & $\begin{array}{l}\text { Growth in earnings before interest and taxes } \\
\text { (EBIT percent) has been ... }\end{array}$ & 0.781 \\
\hline & Growth in market share has been ... & 0.759 \\
\hline
\end{tabular}

LO, logistics outsourcing; LOP, logistics outsourcing performance; LP, logistics performance LSPS, logistics service providers; FP, firm performance; SEM, structural equation modelling.

TABLE 3: Measurement model evaluation.

\begin{tabular}{lccc}
\hline Latent construct & AVE & $\begin{array}{c}\text { Composite } \\
\text { reliability }\end{array}$ & $\begin{array}{c}\text { Discriminant } \\
\text { validity problem? }\end{array}$ \\
\hline Firm performance & 0.65 & 0.90 & No \\
Logistics outsourcing & 0.56 & 0.81 & No \\
Logistics outsourcing performance & 0.61 & 0.95 & No \\
Logistics performance & 0.67 & 0.91 & No \\
\hline
\end{tabular}

AVE, average variance extracted. 
The $f^{2}$ values for the model's $R^{2}$ were interpreted based on Cohen's (1988) critical values and revealed that LO had a small effect on FP (0.002) and LP (0.013). Similarly, LOP had a small effect on FP (0.047), but a medium effect on LP (0.176). Finally, LP had a medium effect on FP (0.166). The model revealed that $Q^{2}>0$ (i.e. $\mathrm{FP}=0.174 ; \mathrm{LOP}=0.081 ; \mathrm{LP}=0.132$ ), thus indicating the model had predictive relevance, as per Chin (1998). Statistical significance of the path coefficients was also examined to identify statistically significant relationships and to test the research hypotheses. The results revealed that the direct effect of LO on FP was not statistically significant $(t$-statistics $<1.96)$ at a $95 \%$ confidence interval. However, path coefficients representing hypotheses $\mathrm{H}_{3}, \mathrm{H}_{4^{\prime}}$ $\mathrm{H}_{5}$ and $\mathrm{H}_{6}$ were statistically significant ( $t$-statistics >1.96). The mediating effect of LOP on the effect of LO on FP was statistically significant. However, the mediating effect of LP on the effect of LO on FP was not statistically significant. The hypothesis testing result is illustrated in Table 4, revealing that hypotheses $\mathrm{H}_{1}$ and $\mathrm{H}_{2}$ were rejected, while $\mathrm{H}_{3^{\prime}}, \mathrm{H}_{4^{\prime}}, \mathrm{H}_{5}$ and $\mathrm{H}_{6}$ were accepted.

\section{Discussion}

The motivation for logistics outsourcing among manufacturing SMEs included cost reduction, risk sharing, access to expert LSPs' capabilities that lack in-house as well as focus on the core business of manufacturing. These reasons have been echoed across the globe, as highlighted in the studies by Langley and Capgemin (2016), Solakivi et al. (2011) and Waugh and Luke (2011).

The process followed in logistics outsourcing is critical in selecting the right LSP that can help the SMEs achieve the objectives of outsourcing. As highlighted in the previous section, SMEs could be using ad hoc methods when implementing logistics outsourcing strategy. To achieve improved SME performance through logistics outsourcing, a logistics outsourcing model is proposed at the end of this section.

\begin{tabular}{|c|c|c|c|}
\hline Hypotheses & $\begin{array}{l}\text { Path } \\
\text { coefficients }\end{array}$ & $\begin{array}{l}t \text {-statistics } \\
(|\mathrm{O} / \mathrm{STDEV}|)\end{array}$ & $\begin{array}{l}\text { Accept } \\
\text { or reject }\end{array}$ \\
\hline $\begin{array}{l}\mathrm{H}_{1} \text { : Logistics outsourcing has a positive } \\
\text { effect on firm performance. }\end{array}$ & 0.037 & 0.440 & Reject \\
\hline $\begin{array}{l}\mathrm{H}_{2} \text { : Logistics outsourcing has a positive } \\
\text { effect on logistics performance. }\end{array}$ & 0.109 & 1.605 & Reject \\
\hline $\begin{array}{l}\mathrm{H}_{3} \text { : Logistics outsourcing has a positive } \\
\text { effect on logistics outsourcing } \\
\text { performance. }\end{array}$ & $0.378 * *$ & 6.500 & Accept \\
\hline $\begin{array}{l}\mathrm{H}_{4} \text { : Logistics outsourcing performance } \\
\text { has a positive effect on logistics } \\
\text { performance. }\end{array}$ & $0.403^{* *}$ & 5.217 & Accept \\
\hline $\begin{array}{l}\mathrm{H}_{5} \text { : Logistics outsourcing performance } \\
\text { has a positive effect on firm } \\
\text { performance. }\end{array}$ & $0.215^{* *}$ & 2.749 & Accept \\
\hline $\begin{array}{l}\mathrm{H}_{6} \text { : Logistics performance has a positive } \\
\text { effect on firm performance. }\end{array}$ & $0.387^{* *}$ & 5.219 & Accept \\
\hline $\begin{array}{l}\mathrm{H}_{7} \text { : Logistics outsourcing performance } \\
\text { mediates the relationship between } \\
\text { logistics outsourcing and firm } \\
\text { performance. }\end{array}$ & - & $2.889 *$ & Accept \\
\hline $\begin{array}{l}\mathrm{H}_{8}: \text { Logistics performance mediates the } \\
\text { relationship between logistics } \\
\text { outsourcing and firm performance. }\end{array}$ & - & 0.789 & Reject \\
\hline
\end{tabular}

\section{Effect of logistics outsourcing on firm performance}

The direct relationship between logistics outsourcing and firm performance was positive, as predicted, but not statistically significant. This finding provided an empirical validation of the results reported in the studies by Chatzoglou and Sarigiannidis (2009) and Hsiao et al. (2011) studies, which found no statistically significant relationship between logistics outsourcing and performance. Similarly, it partly supported the Cho et al.'s (2008) study, which found no statistically significant effect of logistics outsourcing on firm performance. This result suggests that logistics outsourcing benefits relating to performance of manufacturing SMEs are not straightforward as earlier expected, but might be dependent on factors other than just outsourcing, as also argued by Solakivi et al. (2011). The finding might also imply that the manufacturing SMEs in Nairobi outsourced their logistics for reasons other than just to improve their performance. Some of the reasons were identified as a lack of in-house capabilities, to reduce logistics costs, an aversion to risk and a desire to free management time to focus on core activities. Finally, logistics outsourcing could be used as a long-term restructuring strategy by the SMEs and not just to achieve financial and customer satisfaction goals, because the majority of the SMEs had $<5$ years' experience with logistics outsourcing. Thus, it is likely that this strategy would yield performance-related benefits into the future (Zailani et al. 2017).

\section{Mediating effect of logistics outsourcing performance}

Logistics outsourcing performance as a mediating variable provides a deep understanding and a clear explanation of how logistics outsourcing influences firm performance (Baron \& Kenny 1986; MacKinnon \& Fairchild 2009). This study revealed that LO has a statistically significant positive indirect effect on FP through LOP as a mediating variable. As highlighted earlier, communication, trust, cooperation and innovation were identified as measures of logistics outsourcing performance. Thus, manufacturing SMEs practicing logistics outsourcing should focus on the quality of communication, building high trust levels, nurturing close cooperation with 3PLs and aiding 3PLs to enhance their innovative capabilities to improve performance. The positive indirect effect of logistics outsourcing on firm performance validates the results in the Hsiao et al.'s (2011) study. The indirect effect also validates partly the finding in the Solakivi, Töyli and Ojala (2013) study, which argued that upon logistics outsourcing, cooperation between SMEs and 3PLs results in customer satisfaction. Similarly, the result also supported the findings of the Lin, Pekkarinen and Ma (2015) study which highlighted close cooperation between manufacturer and 3PL as an important factor through which logistics outsourcing can positively influence enterprise performance. This is because cooperation promotes good communication, the building of trust and innovation, thus making it easier for the enterprise to understand how the services offered by a 3PL can influence its performance and make suggestions on any modifications required to achieve the expected results (Lin et al. 2015). 
This finding could imply further that the maintenance of good communication, high trust levels, close cooperation and 3PL innovation reduce contract management costs and other relationship costs, making it possible for the SMEs to reap the benefits of logistics outsourcing, such as reduced logistics operations and fixed costs.

\section{Proposed logistics outsourcing model}

Some of the manufacturing SMEs in this study had a formalised process of logistics outsourcing, although not designed to result in improved performance. In addition, it is established in this study that LO has an indirect influence on FP via LOP. To achieve tangible benefits to SMEs based on these findings, there is need to develop a logistics outsourcing model to guide the LO process among SMEs to achieve improved performance. Hitherto, SMEs do acquire expert LSPs' capabilities to reduce costs and risks and to focus on core business in line with the RBV and TCE theories. Therefore, applying the findings of this study, a logistics outsourcing model is deduced along the critical path LO-LOP-LP-FP (Figure 3). The selected path has the highest statistically significant path coefficients, depicting a strong relationship (see Figure 3).

SMEs expecting to apply the proposed logistics outsourcing model are expected to do it through a rigorous process. Steps antecedent to the application of the proposed logistics model include the following: (1) a thorough information search to identify the reasons for outsourcing; (2) select the right activity to outsource to achieve objective in (1); (3) the right LSP that will better perform the activity selected in (2). Upon selecting an LSP, the proposed model is applied by (4), negotiating a favourable contract with the selected LSP. The contract should promote LOP attributes (i.e. quality

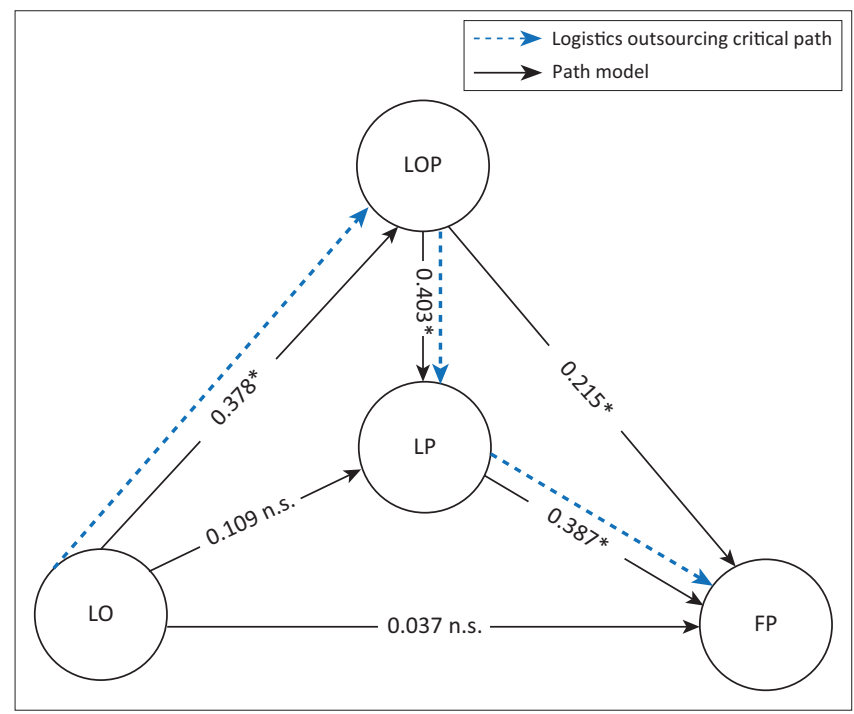

Note: The arrows indicate direction of construct relationship; the figures on the arrows indicate the path coefficients.

LO, logistics outsourcing; LOP, logistics outsourcing performance; LP, logistics performance; $\mathrm{FP}$, firm performance; n.s., not statistically significant $(p>0.05)$

$*$, statistically significant $(p<0.05)$.

FIGURE 3: Logistics outsourcing critical path model for small and medium-sized enterprises. communication, building high trust levels, nurturing a close cooperative relationship with the LSPs and enhancing innovative capabilities of the selected LSPs). High LOP would ensure that (5) LP goals such as cost reduction, risk reduction, meeting of delivery times, the provision of quality goods and the seamless flow of goods are achieved. The achievement of LP goals could lead to better (6) FP in terms of improved profitability, customer satisfaction, return on capital employed, ROA, and increased sales and market share. Thus, manufacturing SMEs could focus on the path LO-LOP-LP-FP when practicing LO to improve performance, as illustrated in Figure 2. This path was selected because it had the highest path coefficients, signifying the strongest significant relationship paths in the model. It requires that upon logistics outsourcing, SMEs should focus on logistics outsourcing performance to improve logistics performance. Improved logistics performance might result in improved firm performance (Zailani et al. 2017). The deduced process upon applying the logistics outsourcing model is summarised, as illustrated in Table 5.

\section{Conclusion}

Manufacturing SMEs in Nairobi might be practising logistics outsourcing to achieve benefits beyond firm performance, for instance, to acquire logistics capabilities that they lack in-house, to share logistics-related risk and a desire to free management time to focus on core activities. However, manufacturing SMEs that endeavour to practise logistics outsourcing to improve their performance should promote high logistics outsourcing performance by fostering quality communication with the selected 3PL, build high trust levels, maintain a close cooperative relationship with selected 3PL and enhance the innovative capabilities of the selected 3PL. Thus, logistics outsourcing has an indirect positive effect on the performance of manufacturing SMEs through logistics outsourcing performance. These findings make important theoretical implications by applying the RBV and TCE theories in studying the relationship between logistics outsourcing and firm performance among SMEs. The findings also extend SME literature by providing a logistics outsourcing model to guide SMEs' outsourcing to improve performance. The study recommends that SME managers follow the one-path model deduced to achieve improved performance. This can be achieved by conducting a thorough information search to

TABLE 5: Deduced process of logistics outsourcing.

\begin{tabular}{|c|c|c|}
\hline Steps & Activity & Explanation \\
\hline 1 & Motivation & Information search to identify reasons for outsourcing \\
\hline 2 & Select activity & $\begin{array}{l}\text { Select the right logistics activity or activities to outsource } \\
\text { to better achieve the motivation }\end{array}$ \\
\hline 3 & Select LSP & $\begin{array}{l}\text { Select the right LSP that will better perform the activity } \\
\text { selected in (2) }\end{array}$ \\
\hline 4 & Contracting & $\begin{array}{l}\text { Negotiate a favourable ('win-win') contract with the } \\
\text { selected LSP. Contract to promote LOP attributes (i.e. } \\
\text { quality communication, trust, cooperation and innovation }\end{array}$ \\
\hline 5 & $\begin{array}{l}\text { Evaluate logistics } \\
\text { performance }\end{array}$ & $\begin{array}{l}\text { Logistics performance evaluation based on cost reduction, } \\
\text { risk reduction, delivery times, quality goods and the } \\
\text { seamless flow of goods }\end{array}$ \\
\hline 6 & $\begin{array}{l}\text { Evaluate firm } \\
\text { performance }\end{array}$ & $\begin{array}{l}\text { Evaluate impact of LO on FP (profitability, customer } \\
\text { satisfaction, return on capital employed, return on assets } \\
\text { and market share) }\end{array}$ \\
\hline
\end{tabular}

LO, logistics outsourcing; LOP, logistics outsourcing performance; FP, firm performance; LSP, logistics service provider. 
identify the need and then select the right activity and the right 3PL service provider. Once a $3 \mathrm{PL}$ is selected, a contract should be entered that promotes logistics outsourcing performance attributes. High logistics outsourcing performance ensures high logistics performance goals are achieved. The achievement of logistics performance goals will lead to better firm performance.

The findings presented in this research are limited to manufacturing SMEs in Nairobi. Future research should expand the study to other contexts, such as the whole country or region, and test the model. This study tested the relationship between logistics outsourcing and firm performance through logistics outsourcing performance and logistics performance as mediating variables. Future studies can test this relationship via different mediator or moderator variables. The findings presented relied on cross-sectional data. Longitudinal studies in future will provide better understanding of the tested model.

\section{Acknowledgements Competing interests}

The authors declare that they have no financial or personal relationship(s) that may have inappropriately influenced them in writing this article.

\section{Authors' contributions}

G.P., R.L. and J.M. collaborated in the conception and design of the research. J.M. collected, analysed and interpreted the data and drafted the manuscript. R.L. and G.P. critically revised the manuscript and approved the final version to be published.

\section{References}

Armstrong, S.J. \& Overton, S.T., 1977, 'Estimating nonresponse bias in mail surveys', Journal of Marketing Research 14, 396-402. https://doi.org/10.2307/3150783

Baron, R.M. \& Kenny, D.A., 1986, 'The moderator-mediator variable distinction in social psychological research', Journal of Personality and Social Psychology 51(6), 1173-1182. https://doi.org/10.1037/0022-3514.51.6.1173

Bolumole, Y.A., Frankel, R. \& Naslund, D., 2007, 'Developing a theoretical framework for logistics outsourcing', Transportation Journal 46(2), 35-54.

Bowen, M., Morara, M. \& Mureithi, S., 2009, 'Management of business challenges among small and micro enterprises in Nairobi-Kenya', KCA Journal of Business Management 2(1), 16-23. https://doi.org/10.4314/kjbm.v2i1.44408

Buculescu, M.M., 2013, 'Harmonization process in defining small and medium-sized enterprises. Arguments for a quantitative definition versus a qualitative one', Theoretical and Applied Economics 20(9), 103-114.

Chatzoglou, P.D. \& Sarigiannidis, L., 2009, 'Business outsourcing and organisational performance: The case of the Greek hotel industry', International Journal of Services Technology and Management 11(2), 105-127. https://doi.org/10.1504/ IJSTM.2009.022520

Chege, J., Ngui, D. \& Kimuyu, P., 2016, Scoping paper on Kenyan manufacturing. Learning to compete, working paper No.25. Brookings Institution, viewed 19 September 2016, from https://www.brookings.edu/wp-content/uploads/2016/07/ L2C WP25-1.pdf

Chen, J., 2006, 'Development of Chinese small and medium-sized enterprises', Journal of Small Business and Enterprise Development 13(2), 140-147. https://doi. org/10.1108/14626000610665854

Chew, R. \& Chew, S.B., 2008, 'A study of SMEs in Singapore', Journal of Enterprising Communities: People and Places in the Global Economy 2(4), 332-347. https:// doi.org/10.1108/17506200810913908

Chin, W., 1998, 'The partial least squares approach to structural equation modelling', in G.A. Marcoulides (ed.), Modern methods for business research, pp. 295-358, Lawrence Erlbaum Associates, Mahwah NJ.

Cho Joong-Kun, J., Ozment, J. \& Sink, H., 2008, ‘Logistics capability, logistics outsourcing and firm performance of small electronic appliances manufacturers', Computers and Industrial Engineering 38(5), 336-359.
Cohen, J., 1988, Statistical power analysis for the behavioral sciences, 2nd edn., Lawrence Erlbaum Ass., Hillsdale, NJ.

Creswell, J.W., 2014, Research design: Qualitative, quantitative and mixed methods approaches, 4th edn., Sage, Thousand Oaks, CA.

Creswell, J.W. \& Clark, V.L.P., 2007, Designing and conducting mixed methods research, Sage, Thousand Oaks, CA.

Creswell, J. \& Clark, V.L.P., 2011, Designing and conducting mixed methods research, Sage, Thousand Oaks, CA

Das, K., 2008, 'SMEs in India: Issues and possibilities in times of globalisation', in H. Lim (ed.), SME in Asia and globalization, ERIA Research Project Report 2007-5, pp. 69-97, viewed 27 April 2018, from http://www.eria.org/SMEs\%20in\%20lndia pp. 69-97, viewed 27 April 2018, from http://www.eria.org/SMEs $\% 20 \mathrm{in} \% 201$
Issues $\% 20$ and $\% 20$ Possibilities $\% 20$ in $\% 20$ Times $\% 20$ of $\% 20$ Globalisation.pdf

Davcik, S.N., 2014, 'The use and misuse of structural equation modeling in management research: A review and critique', Journal of Advances in Management Research 11(1), 47-81. https://doi.org/10.1108/JAMR-07-2013-0043

Deepen, J.M., Goldsby, T.J., Knemeyer, A.M. \& Wallenburg, C.M., 2008, 'Beyond expectations: An examination of logistics outsourcing goal achievement and goal exceedance', Journal of Business Logistics 29(2), 75-105. https://doi.org/10.1002/ j.2158-1592.2008.tb00088.

Fawcett, S.E., Magnan, G.M. \& McCarter, M.W., 2008, 'Benefits, barriers, and bridges to effective supply chain management', Supply Chain Management: An International Journal 13(1), 35-48. https://doi.org/10.1108/13598540810850300

Gill, A. \& Biger, N., 2012, 'Barriers to small business growth in Canada', Journal of Small Business and Enterprise Development 19(4), 656-668. https://doi.org/10.1108/ 14626001211277451

Government of Kenya, 2007, Kenya Vision 2030, Government Printer, Nairobi.

Government of Kenya, 2012, Small and Micro-Enterprises Act, Government Printer, Nairobi.

Green, K.W., Whitten, D. \& Inman, R.A., 2008, 'The impact of logistics performance on organizational performance in a supply chain context', Supply Chain Management: An International Journal 13(4), 317-327. https://doi.org/10.1108/13598540810 882206

Hair, J.F., Hult, G.T.M., Ringle, C. \& Sarstedt, M., 2014, A primer on partial least squares structural equation modeling (PLS-SEM), Sage, Thousand Oaks, CA.

Halldorsson, A., Kotzab, H., Mikkola, J. \& Skjøtt- Larsen, T., 2007, ‘Complementary theories to supply chain management', Supply Chain Management: An International Journal 12(4), 284-296. https://doi.org/10.1108/13598540710759808

Hsiao, H.I., Kemp, R.G., Van der Vorst, J.G. \& Omta, S.W.F., 2011, 'Logistics outsourcing by Taiwanese and Dutch food processing industries', British Food Journal 113(4), 550-576. https://doi.org/10.1108/00070701111124014

Hsiao, H.I., Van der Vorst, J.G.A.J., Kemp, R.G.M. \& Omta, S.W.F., 2010, 'Developing a decision-making framework for levels of logistics outsourcing in food supply chain networks' International Journal of Physical Distribution \& Logistics Management 40(5), 395-414. https://doi.org/10.1108/09600031011052840

Huo, B., Ye, Y. \& Zhao, X., 2015, 'The impacts of trust and contracts on opportunism in the 3PL industry: The moderating role of demand uncertainty', International Journal of Production Economics 170, 160-170. https://doi.org/10.1016/j.ijpe. 2015.09.018

Jogulu, U.D. \& Pansiri, J., 2011, 'Mixed methods. A research design for management doctoral dissertations', Management Research Review 34(6), 687-701. https:// doi.org/10.1108/01409171111136211

Karikomi, S., 1998, The development strategy for SMEs in Malaysia, viewed 27 April 2018, from http://www.ide.go.jp/library/English/Publish/Download/Apec/pdf/ 1997_11.pdf

Kasie, F.M. \& Belay, A.M., 2013, 'The impact of multi-criteria performance measurement on business performance improvement', Journal of Industrial Engineering and Management 6(2), 595. https://doi.org/10.3926/jiem.489

Kenya National Bureau of Statistics, 2016, Micro, small and medium establishment (MSME) survey, viewed 27 April 2018, from https://www.knbs.or.ke/download/ 2016-msme-basic-report/

Kimuyu, P., 2010, 'Do small firms in developing countries ever transform?', Regiona Development Studies 14, 11-28.

König, A. \& Spinler, S., 2016, 'The effect of logistics outsourcing on the supply chain vulnerability of shippers: Development of a conceptual risk management framework', The International Journal of Logistics Management 27(1), 122-141. https://doi.org/10.1108/IJLM-03-2014-0043

Kotabe, M. \& Mol, M.J., 2009, 'Outsourcing and financial performance: A negative curvilinear effect', Journal of Purchasing and Supply Management 15(4), 205-213. https://doi.org/10.1016/j.pursup.2009.04.001

Križman, A. \& Ogorelc, A., 2010, 'Impact of disturbing factors on cooperation in logistics outsourcing performance: The empirical model', PROMET-Traffic \& Transportation 22(3), 209-218. https://doi.org/10.7307/ptt.v22i3.277

Krosnick, J.A. \& Presser, S., 2010, 'Question and questionnaire design', in Handbook of survey research, pp. 263-313, 2nd edn., Emerald, viewed 27 April 2018, from https://studysites.sagepub.com/kumar4e/study/Chapter\%209/Questionnaires.pdf

Lahiri, S., 2015, 'Does outsourcing really improve firm performance? Empirical evidence and research agenda', International Journal of Management Reviews 00 $1-35$.

Langley, J. \& Capgemini, 2016, 2017 third-party logistics study - The state of logistics outsourcing results and findings of the 21st annual study, viewed 05 October 2016 from http://www.3plstudy.com/media/downloads/2016/09/2017-report.pdf

Langley, J. \& Capgemini, 2017, 2018 third-party logistics study - the state of logistics outsourcing, results and findings of the 22nd annual study, viewed 27 April 2018, from http://www.3plstudy.com/3pl2018download.php 
Lee, C.C., Lin, T.T. \& Cheng, P.C., 2013, 'The determinants of the transportation outsourcing strategy for the express delivery company', Service Business $7(2)$ 207-225. https://doi.org/10.1007/s11628-012-0151-0

Leuschner, R., Carter, R.C., Goldsby, J.T. \& Rogers, S.Z., 2014, 'Third-party logistics: A meta-analytic review and investigation of its impact on performance', Journal of Supply Chain Management 50(1), 21-43. https://doi.org/10.1111/jscm.12046

Lieb, R.C. \& Randall, H.L., 1996, 'A comparison of the use of third-party logistics services by large American manufacturers 1991, 1994 and 1995', Journal of Business Logistics 17(1), 305-320.

Lin, Y., Pekkarinen, S. \& Ma, S., 2015, 'Service-dominant logic for managing the logisticsmanufacturing interface: A case study', The International Journal of Logistic Management 26(1), 195-214. https://doi.org/10.1108/IJLM-08-2013-0095

Liu, C., Huo, B., Liu, S. \& Zhao, X., 2015, 'Effect of information sharing and process coordination on logistics outsourcing', Industrial Management \& Data System 115(1), 41-63. https://doi.org/10.1108/IMDS-08-2014-0233

Mackinnon, D.P. \& Fairchild, A.J., 2009, 'Current directions in mediation analysis', Current Directions in Psychological Science 18(1), 16-20. https://doi.org/10.1111/ j.1467-8721.2009.01598.x

Marchand, M. \& Raymond, L., 2008, 'Researching performance measurement systems: An information systems perspective', International Journal of Operations
\& Production Management 28(7), 663-686. https://doi.org/10.1108/0144357 $\&$ Production
0810881802

Murphy, P.J., Wu, Z., Welsch, H., Heiser, D.R., Young, S.T. \& Jiang, B., 2012, 'Small firm entrepreneurial outsourcing: Traditional problems, nontraditional solutions', Strategic Outsourcing: An International Journal 5(3), 248-275. https://doi.org/ Strategic Outsourcing: An Intern
10.1108/17538291211291774

Nasr, S. \& Rostom, A., 2013, SME contributions to employment, job creation, and growth in the Arab world, Policy Research working paper; no. WPS 6682, viewed 25 September 2016, from http://documents.worldbank.org/curated/ en/301631468278944687/SME-contributions-to-employment-job-creation-andgrowth-in-the-Arab-world

Oshri, I., Kotlarsky, J. \& Gerbasi, A., 2015, 'Strategic innovation through outsourcing: The role of relational and contractual governance', The Journal of Strategic Information Systems 24(3), 203-216. https://doi.org/10.1016/j.jsis.2015.08.001

Pallant, J., 2010, SPSS survival manual: A step by step guide to data analysis using SPSS, 4th edn., McGraw-Hill Education, New York.

Papadavid, P., 2016, The role of finance in Kenyan manufacturing. A scoping paper viewed 25 April 2018, from https://set.odi.org/wp-content/uploads/2016/09/ The-Role-of-Finance-in-Kenyan-Manufacturing-Phyllis-Papadavid.pdf

Parashkevova, L., 2007, 'Logistics outsourcing - A means of assuring the competitive advantage for an organization', Vadyba/Management 2(15), 29-38.

Pratap, S., 2014, 'Towards a framework for performing outsourcing capability', Strategic Outsourcing: An International Journal 7(3), 226-252. https://doi.org/10.1108/SO 04-2014-0004

Quang, H.T., Sampaio, P., Carvalho, M.S., Fernandes, A.C., Binh An, D.T. \& Vilhenac, E., 2016, 'An extensive structural model of supply chain quality management and firm performance', International Journal of Quality \& Reliability Management 33(4), 444-464. https://doi.org/10.1108/IJQRM-11-2014-0188

Rahman, S. \& Wu, J., 2011, 'Logistics outsourcing in China: The manufacturer-cumsupplier perspective', Supply Chain Management: An International Journal 16(6), 462-473. https://doi.org/10.1108/13598541111171156

Raymond, L., Marchand, M., St-Pierre, J., Cadieux, L. \& Labelle, F., 2013, 'Dimensions of small business performance from the owner-manager's perspective: A reconceptualization and empirical validation', Entrepreneurship \& Regional Development 25(5-6), 468-499. https://doi.org/10.1080/08985626.2013.782344
Richter, N.F., Sinkovics, R.R., Ringle, C.M. \& Schlägel, C., 2016, 'A critical look at the use of SEM in international business research', International Marketing Review 33(3), 376-404. https://doi.org/10.1108/IMR-04-2014-0148

Ringle, C.M., Wende, S. \& Becker, J.-M., 2015, SmartPLS 3, SmartPLS GmbH, Bönningstedt.

Saunders, N.K.M., Lewis, P. \& Thornhill, A., 2016, Research Methods for Business Students, 7th edn., Pearson Educational Publishers, Harlow, England.

Soinio, J., Tanskanen, K. \& Finne, M., 2012, 'How logistics-service providers can develop value-added services for SMEs: A dyadic perspective', International Journal of Logistics Management 23(1), 31-49. https://doi.org/10.1108/09574091211226911

Solakivi, T., Töyli, J., Engblom, J. \& Ojala, L., 2011, 'Logistics outsourcing and company performance of SMEs: Evidence from 223 firms operating in Finland', Strategic Outsourcing: An International Journal 4(2), 131-151. https://doi.org/10.1108/ 17538291111147982

Solakivi, T., Töyli, J. \& Ojala, L., 2013, 'Logistics outsourcing, its motives and the level of logistics costs in manufacturing and trading companies operating in Finland' Production Planning \& Control 24(4-5), 388-398. https://doi.org/10.1080/09537 287.2011.648490

Sonobe, T., Akoten, J.E. \& Otsuka, K., 2011, 'The growth process of informal enterprises in Sub-Saharan Africa: A case study of a metalworking cluster in Nairobi', Small Business Economics 36(3), 323-335. https://doi.org/10.1007/s11187-009-9222-6

Sople, V.V., 2012, Logistics management: The supply chain imperative, 3rd edn., Dorling Kindersley, Pearson, India.

Takkashori, A. \& Teddlie, C. (eds.), 2010, Mixed methods in social \& behavioral research, Sage, Thousand Oaks, CA.

Töyli, J., Häkkinen, L., Ojala, L. \& Naula, T., 2008, 'Logistics and financial performance: An analysis of 424 Finnish small and medium-sized enterprises', International Journal of Physical Distribution \& Logistics Management 38(1), 57-80. https://doi. org $/ 10.1108 / 09600030810857210$

Tseng, P. \& Liao, C., 2015, 'Supply chain integration, information technology, market orientation and firm performance in container shipping firms', The International Journal of Logistics Management 26(1), 82-106. https://doi.org/10.1108/IJLM09-2012-0088

Van Laarhoven, P., Berglund, M. \& Peters, M., 2000, 'Third-party logistics in Europe Five years later', International Journal of Physical Distribution \& Logistics Management 30(5), 425-442. https://doi.org/10.1108/09600030010336216

Wagner, S. \& Franklin, J., 2008, 'Why LSPs don't leverage innovations', Supply Chain Quarterly 2(4), 66-71.

Waugh, B. \& Luke R., 2011, 'Logistics outsourcing by manufacturers in South Africa', Journal of Transport and Supply Chain Management 5(1), 337-360. https://doi. org/10.4102/jtscm.v5i1.81

Were, A., 2016, Manufacturing in Kenya: Features, challenges and opportunities. A scoping exercise, viewed 25 April 2018, from https://set.odi.org/wp-content/ uploads/2016/09/Manufacturing-in-Kenya-Anzetse-Were.pdf

Wong, C.Y. \& Karia, N., 2010, 'Explaining the competitive advantage of logistics service providers: A resource-based view approach', International Journal of Production Economics 128(1), 51-67. https://doi.org/10.1016/j.ijpe.2009.08.026

Yang, C.C., Marlow, P.B. \& Lu, C.S., 2009, 'Assessing resource, logistics service capabilities, innovation capabilities and the performance of container shipping services in Taiwan', International Journal of Production Economics 122(1), 4-20. https://doi. org/10.1016/j.ijpe.2009.03.016

Zailani, S., Shaharudin, M.R., Razmi, K. \& Iranmanesh, M., 2017, 'Influential factors and performance of logistics outsourcing practices: An evidence of Malaysian companies', Review of Managerial Science 11(1), 53-93. https://doi.org/10.1007/ s11846-015-0180-x 